\title{
Pengaruh Special Event Pembukaan ASIAN GAMES ke-18 Tahun 2018 terhadap Reputasi Ketua Panitia INASGOC
}

\author{
Alfilonia Harwinda, Andre Ikhsano \\ Institut Komunikasi dan Bisnis LSPR \\ Email: alfiloniaharwindaa@gmail.com
}

DOI: https://doi.org/10.21107/ilkom.v14i1.6029

\begin{abstract}
ABSTRAK
Penelitian ini penting karena dilihat dari kesuksesan pembukaan acara Asian Games ke-18 tahun 2018 yang megah dan spektakuler berkaitan dengan reputasi ketua panitia INASGOC. Tujuan penelitian ini untuk menganalisa adakah pengaruh dan seberapa besar pengaruh special event pembukaan Asian Games ke 18 tahun 2018 terhadap reputasi ketua panitia INASGOC dari sudut pandang teori harapan melalui special event, dan reputasi. Dalam penelitian ini ada 2 variabel yaitu variabel $X$ (special event) menggunakan 8 dimensi terdiri dari uniqueness, perishability, intangibility, ritual or ceremony, ambience and service, personal contact and interaction, labour intensive, dan fixed timescale sedangkan variabel Y (reputasi) menggunakan 4 dimensi terdiri dari kredibilitas, terpercaya, keterandalan dan tanggung jawab sosial. Penelitian ini melalui metode penelitian kuantitatif dengan menguji regresi linear sederhana, koefisien persamaan regresi, uji anova, analisis korelasi, dan uji normalitas. Responden dalam penelitian ini adalah 100 orang responden yang menonton langsung pembukaan Asian Games ke-18 tahun 2018 di Gelora Bung Karno Jakarta. Penelitian ini mendapatkan hasil dari Pearson Correlation Product Moments menunjukkan sebesar 0,628 bahwa terdapat pengaruh positif dan kuat yang signifikan antara special event pembukan Asian Games ke-18 tahun 2018 terhadap reputasi ketua panitia INASGOC. Penelitian ini juga terdapat besar pengaruh special event pembukaan Asian Games ke-18 tahun 2018 terhadap reputasi ketua panitia INASGOC adalah 39,4\%..
\end{abstract}

Kata kunci: teori harapan, special Event, reputasi

\section{ABSTRACT}

The purpose of this research is to analyze what is the effect of influence and how much they influence the special event opening ceremony of the 18th Asian Games in 2018 affected to the reputation of the INASGOC committee chairman by using expectancy theory, special event, and reputation. This research which uses 2 variables such are Variable $X$ (special event) are using 8 dimension such are uniqueness, perishability, intangibility, ritual or ceremony, ambience and service, personal contact and interaction, labour intensive, and fixed timescale while for variable $Y$ (reputation) are using 4 dimensions such are credibility, trustworthiness, reliability and social responsibility. This research through a quantitative research method with regression linear, coefficient regression, ANOVA, correlations, frequency distribution table, and normality distribution. This research with 100 respondenses watched the live opening ceremony of the 18th Asian Games in 2018 at Gelora Bung Karno Jakarta. The result of the research is that are of influence of the special event opening ceremony of the 18th Asian Games in 2018 to the reputation of the INASGOC committee chairman of $39,4 \%$

Keyword: expectancy theory, special event, and reputation

\footnotetext{
Cite this as :

Harwinda, A., \& Ikhsano, A. (2020). Pengaruh Special Event Pembukaan ASIAN GAMES ke-18 Tahun 2018 terhadap Reputasi Ketua Panitia INASGOC. Jurnal Komunikasi, 14(1), 3142. doi : https://doi.org/10.21107/ilkom.v14i1.6029

Article History : Received December, $9^{\text {th }} 2019$, Acepted January, $9^{\text {th }} 2020$ 


\section{PENDAHULUAN}

Asian Games adalah pertandingan olahraga terbesar se-Asia, pertama kali digelar pada tahun 1951 di Delhi, India dan telah dilaksanakan 18 kali dalam 4 tahun sekali di 10 negara. Indonesia pernah mendukung untuk sukses dalam acara pertandingan olahraga yang terbesar di Asia. Sejarah singkat pada tahun 1962 Indonesia menjadi tuan rumah pertama kali untuk Asian Games ke-4 dan tahun 2018 terpilihnya di Indonesia sebagai tuan rumah kedua kalinya khususnya di daerah Provinsi Jakarta dan Palembang yang mana Indonesia menjadi terkenal oleh seluruh di negara Asia.

Acara terbesar se-Asia untuk pertandingan olahraga bertaraf Internasional adalah perayaan pembukaan Asian Games Ke-18 Tahun 2018 Jakarta dan Palembang di Stadion Utama Gelora Bung Karno, Jakarta yang diorganisasikan oleh INASGOC (Indonesia Asian Games Organizing Committee). Acara dengan pertunjukan yang meriah, spektakuler dan sakral serta panggung yang megah dan terbesar dalam pembukaan kejuraan olahraga multi event yang pernah ada, dibagi menjadi empat unsur elemen kekayaan alam terdiri dari air, bumi, tanah dan angin yang mewakili nilai-nilai luhur bangsa Indonesia (Sari, 2018).

Erick Thohir menyatakan di website sport detik.com bahwa perayaan pembukaan Asian Games ke-18 tahun 2018 yang dihadiri 40.000 orang penonton, tamu undangan sekitar 5.000 orang tamu dan atlet ada 6.000 orang atlet dari seluruh cabang olahraga seAsia. Jadi total penonton berjumlah 51.000 orang penonton (Raya, 2018).

Acara terbesar dalam kategori kelas dunia yang diselenggarakan di Indonesia, pengunjung dan peserta olahraga dari Internasional dapat mengetahui kebudayaan Indonesia yang beraneka ragam dan keindahan alam dari panggung serta mampu menyukseskan acara dari awal hingga akhir. Penonton yang melihat opening ceremony Asian Games 2018 mengaku puas dengan suguhan hiburan yang ditampilkan oleh panitia serta dari warga Korea mengaku sangat puas dengan menonton keragaman budaya Indonesia dan mendapat pelajaran tentang budaya Indonesia serta panitia dan sukarelawan yang ramah dan baik (Baqiroh, 2018).

Perayaan pembukaan acara yang memberikan hasil baik dan sukses kepada masyarakat Indonesia maupun Internasional untuk lebih mengenal budaya Indonesia. Erick Thohir sebagai ketua panitia INASGOC mulai membangun reputasi dari tahun 2016 untuk tetap fokus dalam merancang dan sebagai manajemen proses menuju hari dimulai dengan acara utama dan penutupan dimana revitalisasi dalam berbagai bidang seperti merekrut relawan dan panitia serta persiapan keperluan maupun lokasi untuk pembukaan acara utama maupun pertandingan dan jasa transportasi untuk atlet-atlet yang digunakan selama Asian Games 2018 berlangsung.

Erick Thohir mendapatkan berbagai apresiasi dari petinggi-petinggi Indonesia maupun Internasional terdiri dari Dewan Olimpiade Asia (OCA), Menteri Perdagangan Republik Indonesia, dan Perdana Menteri Korea Selatan yang takjub dengan pembukaan acara Asian Games 2018 berjalan dengan lancar, mewah dan membawa energi positif kepada seluruh dunia dan berhasil menunjukkan Indonesia mampu sebagai tuan rumah dengan menampilkan standar tinggi seAsia di tahun 2018.

Erick Thohir menjadi dibalik kesuksesan Asian Games 2018 yang terkait dengan bisnis di bidang olahraga. Erick Thohir sedang menjalani sebagai ketua Umum Olimpiade Indonesia dari tahun 2015 sampai tahun 2019 dan Presiden Asosiasi Bola Basket Asia - Tenggara dari tahun 20016 hingga saat ini. Erick Thohir pernah menjadi ketua umum Perbasi pada tahun 2006 sampai tahun 2010, Komandan Kontingen Indonesia untuk Olimpiade London dan Ketua Umum INASGOC dan saat ini menjalani menjadi pengusaha Nasional (Tamtomo, 2018).

Reputasi yang dibangun Erick Thohir menjanjikan acara yang meriah, sakral dan megah guna mendapatkan pandangan positif dari masyarakat Indonesia maupun 
Internasional yang mana mampu membawa pesan persatuan dalam keberagaman toleransi 'Energy of Asia' serta dapat mengendalikan reputasi dalam menjaga image yang positif dari kepanitiaan INASGOC.

Pembukaan acara Asian Games 2018 termasuk dalam special event yang sudah direncanakan, melalui langkah-langkah yang efektif dan disepakati secara professional oleh ketua panitia untuk pertanggung jawaban kegiatan acara sampai selesai untuk mendapatkan hasil pesan positif, menghibur, dan memberikan pengalaman kepada penonton masyarakat yang berada di Indonesia maupun Internasional dan dapat menyelesaikan laporan akhir guna mendapatkan hasil evaluasi yang baik dari acara yang sudah terlaksana. Mengelola acara terbesar dapat menjadi contoh bagi publik guna mendapatkan hasil reputasi yang baik dan sesuai tujuan yang dicapai. Maka dari itu, penelitian ini penting guna mengetahui seberapa besar pengaruh special event pembukaan Asian Games ke-18 tahun 2018 terhadap reputasi ketua panitia INASGOC untuk melihat tercapai sesuai tujuan dalam kesuksesan pembukaan acara Asian Games 2018 yang dipimpin oleh Erick Thohir.

Peneliti ingin membuat rumusan masalah yaitu apakah ada pengaruh special event pembukaan Asian Games ke-18 tahun 2018 terhadap reputasi ketua panitia INASGOC?

Tujuan penelitian yang dicapai dalam penelitian sebagai berikut:

1. Untuk mengetahui adakah pengaruh special event pembukaan Asian Games ke-18 tahun 2018 terhadap reputasi ketua panitia INASGOC dari sudut pandang teori harapan.

2. Untuk mengetahui seberapa besar pengaruh special event pembukaan Asian Games ke-18 tahun 2018 terhadap reputasi ketua panitia INASGOC dari sudut pandang teori harapan.

Teori harapan dalam buku yang berjudul "Work and Motivation" adalah motivasi untuk suatu hasil yang ingin dicapai oleh seseorang dari perkiraan yang bersangkutan bahwa tindakannya akan mengarah kepada hasil yang diinginkan. Artinya, apabila seseorang sangat menginginkan sesuatu, dan jalan terbuku untuk memperoleh yang bersangkutan akan berupaya mendapatkannya (Marliani, 2016).

Teori harapan dikemukakan oleh Vroom, teori harapan adalah kekuatan yang memotivasi seseorang bekerja giat dalam melaksanakan pekerjaannya bergantung pada hubungan timbal balik antara apa yang diinginkan dengan kebutuhan dari hasil pekerjaan itu. Berapa besar yakin perusahaan akan memberikan pemuasan bagi keinginan sebagai imbalan atas usaha yang dilakukannya. Bila keyakinan yang diharapkan cukup besar untuk memperoleh kepuasannya, maka akan lebih bekerja keras (Sutrisno, 2009).

Menurut Vroom (dalam Syaiyid, Utami, \& Riza, 2013) mengemukakan tiga terdiri dari:

1. Daya tarik

Pentingnya individu mengharapkan outcome dan penghargaan yang mungkin dapat dicapai dalam bekerja. Variabel ini mempertimbangkan kebutuhankebutuhan individu yang tidak terpuaskan.

2. Kaitan kinerja-penghargaan

Keyakinan individu bahwa dengan menunjukkan kinerja pada tingkat tertentu akan mencapai outcome yang diinginkan.

3. Kaitan upaya-kinerja

Probabilitas yang diperkirakan oleh individu bahwa dengan menggunakan sejumlah upaya tertentu akan menghasilkan kinerja.

Menurut Robbins et al (Surbakti, 2014), teori harapan mempunyai tiga konsep kunci sebagai berikut: valensi menunjukkan seberapa kuat keinginan seseorang untuk memperoleh reward. Expectancy menunjukkan, kemungkinan keberhasilan kerja (performance probability). 
Instrumentalis : Menunjukkan kemungkinan diterimanya reward jika berhasil.

Berdasarkan uraian di atas, menunjukkan suatu keinginan seseorang mencapai harapan hasil kerja guna memperoleh reward. Kekuatan seseorang dinilai dari kepercayaan untuk mencapai suatu tujuan yang diinginkan dari awal.

Special event pertama kali ditemukan oleh Emile Durkheim tahun 1858-1917 dari ilmuwan Perancis. Special event dirancang untuk menyatukan masyarakat dan memberikan semangat kepada sesama. Menurut Victor Turner menyatakan special event adalah setiap masyarakat merayakan dengan upacara dan ritual sukacita, kesedihan dan kemenangan yang mana hal penting dalam desain, perencanaan, manajemen, dan koordinasi untuk acara khusus. Special event dinyatakan baik dan berhasil dari tim yang dipimpin oleh ketua panitia acara (Goldblatt, 2013).

Special event merupakan acara yang diselenggarakan untuk mendapatkan perhatian dari media dan publik. Dengan diselenggarakannya special event, diharapkan media melakukan pemberitaan positif mengenai perusahaan, produk atau klien yang menyelenggarakan special event tersebut. Special event juga dirancang untuk menyampaikan suatu pesan kepada publik (Hartono, Dida, \& Hafiar, 2016).

Berdasarkan penjelasan di atas, special event adalah acara yang menyatukan masyarakat untuk merayakan upacara pembukaan secara emosional yang memberikan semangat dan meningkatkan interaksi dengan masyarakat dan disebut juga sebagai acara besar yang unik dan didesain sesuai dengan tema acara berdasarkan mengikuti perubahan waktu untuk tercapai target tujuan yang diinginkan.

Menurut Rosady Ruslan (2016) ada dua fungsi untuk special event terdiri dari:

1. Untuk memberikan informasi secara langsung dan mendapatkan hubungan timbal balik yang positif dengan publiknya melalui ajang khusus acara yang sudah dirancang dan dikaitkan dengan program kerja kehumasan.

2. Media komunikasi dan mendapatkan publikasi untuk sasaran target akan memperoleh pengenalan, pengetahuan, pengertian yang mendalam dan diharapkan dari ajang khusus acara untuk menciptakan citra positif terhadap perusahaan atau produk yang diwakilkannya.

Menurut Cutlip et al (dalam Pudjiastuti, 2010, p. xxxvi) special event mempunyai empat tahapan terdiri dari:

\section{Defining the problem (or opportunity)}

Tahapan untuk mendapatkan data dan fakta berkaitan dengan kegiaran yang akan dilakukan, baik melalui opinion research maupun motivation research atau melalui metode penelitian yang lain.

2. Planning and programming

Tahapan perencanaan yaitu membuat proposal kegiatan yang disusun harus berpijak pada data dan fakta yang diperoleh pada saat penelitian yang mana akan menjadi pedoman pada saat pelaksanaan.

3. Taking action and communicating

Tahapan pelaksanaan dari perencanaan yang telah disusun.

4. Evaluating the program

Diperlukan untuk mengetahui apakah kegiatan dilaksanakan berdasarkan pada perencanaan yang telah dibuat dan untuk melihat seberapa jauh tujuan program dapat tercapai.

Menurut Matthews (2016), special event mempunyai unsur yaitu entertainment yang mana ada tiga unsur terdiri dari:

a. Acara hiburan yang menarik dan memiliki perasaan yang kuat.

b. Acara hiburan yang menggunakan emosi.

c. Acara hiburan yang dapat menjadi kenangan dari keseluruhan dalam acara.

Menurut Shone dan Parry (2010, p. 16) special event mempunyai delapan karateristik antara lain: 


\section{Uniqueness}

Elemen kunci dari semua acara special adalah keunikan masing-masing yang berbeda bukan berarti bahwa acara yang sama tidak dapat diulangi, tetapi penonton, lingkungan dan jumlah dari variabelvariabel lainnya akan membuat acara menjadi unik. Keunikan acara dilihat dari format yang berbeda beda dengan acara yang lain. Acara-acara khusus mempunyai banyak karaketiristik atau ciri dan keunikannya terkait dengan aspek tidak daya tahan dan tidak berwujud.

\section{Perishability}

Acara-acara yang unik yang tidak dapat disentuh atau tidak dapat diulang yang bener-bener sama. Peran penyelenggara acara adalah sejauh mana fasilitas dan layanan yang efektif.

\section{Intangibility}

Penyelenggara acara penting memperhatikan dalam benda sekecil apapun guna memperhatikan gagasan hadirin untuk mendapatkan pandangan positif dari orang-orang yang melihat acara langsung.

\section{Ritual or Ceremony}

Ritual dan perayaan adalah isu utama dalam special event. Karakteristik acara utama yang menjadikan istimewa dengan ritual dimana berperan penting untuk menjaga kehormatan yang berkesinambungan dengan perayaan tradisi. Dalam acara ajang khusus acara harus memasuki sesi ritual dan perayaan yang mana penonton dapat menyaksikan acara yang mengajarkan perayaan tradisional untuk menghormati tradisi daerah dan acara menjadi khidmat.

\section{Ambience and Service}

Menciptakan suasana yang lebih baik untuk mendapatkan hasil acara yang sukses. Ambisi dapat dibuat oleh hadirin yang hadir untuk mendapatkan hasil acara yang positif. Penyelenggara acara memperhatikan detail lebih cermat dan jasa pelayanan yang dipersiapkan secara maksimal kepada hadirin yang hadir untuk mendorong hasil yang diinginkan dalam suatu acara yang berhasil.

\section{Personal Contact and Interaction}

Hadirin yang datang menghadiri acara merupakan bagian dari proses. Hadirin saling reaksi, interaksi dan memberikan semangat satu sama lain dan menciptakan pengalaman termasuk dalam pemahaman yang menyeluruh, bagi yang menyaksikan dengan menikmati acara guna mencapai acara yang meriah.

\section{Labour Intensive}

Semakin kompleks dan unik suatu acara maka semakin membutuhkan banyak pekerja baik dalam penyelenggaraan maupun dalam operasional. Organisasi menghubungkan dengan tingkat komunikasi dimana untuk operasi kerja guna mendapatkan hasil kerja yang sesuai keinginan bersama.

\section{Fixed Timescale}

Dalam penyelenggaraan special event skala waktu dapat sangat singkat seperti penyelenggaraan pembukaan acara atau dapat juga sangat panjang. Acara ajang khusus terdiri dari jeda dan aktivitas. Skala waktu perlu diperhatikan untuk menarik pehatian penonton.

Menurut Goldblatt (2013, p. 16) special event mempunyai sepuluh bentuk terdiri dari:

1. Civic events

2. Expositions/exhibitions

3. Fair and festivals

4. Hallmark events

5. Hospitality

6. Meetings and conferences

7. Retail events

8. Social life-cycle events

9. $\quad$ Sports events

10. Tourism 
Berdasarkan di atas, bentuk special event yang sesuai dengan penelitian adalah hallmark events dan sport event.

Menurut Shone \& Parry (2010, p. 5) special event mempunyai empat kategori antara lain:

1. Personal Events

2. Organizational Events

3. Leisure Events

4. Cultural Events

Menurut Gaotsi dan Wilson (dalam Gassing, 2016, p. 160) reputasi adalah evaluasi semua stakeholder terhadap objek atau organisasi yang didasarkan atas pengalaman.

Menurut Helm, Gobbers dan Storck (2011) reputasi adalah konstruksi sosial dapat mengalir baik dengan prinsip yang tepat. Reputasi berdasarkan persepsi yang dibangun dengan baik serta mengharapkan nilai untuk mendapatkan hasil positif yang diinginkan dan dipandang positif dari masyarakat.

Berdasarkan uraian di atas reputasi adalah persepsi yang dibangun berdasarkan pengalaman, memberikan suatu kepercayaan kepada pihak eksternal, reputasi perorangan dapat memperkuat di dalam organisasi maupun perusahaan.

Menurut Gassing dan Suryanto (2016, p. 161) reputasi mempunyai tiga unsur yaitu:

1. Kejujuran

2. Keterbukaan

3. Tanggung Jawab

Menurut Folley dan Kendrik (dalam Triamanah, 2012) reputasi mempunyai tujuh dimensi terdiri dari:

1. Performance

2. Workplace

3. Product

4. Leadership

5. Citizenship

6. Governance

7. Innovation
Menurut Charles J. Fombrun (dalam Aryska \& Kasmirudin, 2017) reputasi mempunyai empat elemen terdiri dari:

1. Kredibilitas

Berkaitan dengan citra perusahaan maupun organisasi yang telah mendapat kepercayaan dari klien, menghargai, dan menghormati perusahaan secara emosional dalam mempercayai aktifitas bisnis perusahaan.

2. Terpercaya

Berkaitan dengan yang mampu menawarkan produk atau jasa yang berkualitas dikelola secara lebih baik agar klien merasa bangga dari perusahaan tersebut.

3. Keterandalan

Berkaitan untuk membangun reputasi yang baik melalui kegiatan dan menjaga kualitas jasa dan menampilkan fasilitasfasilitas yang handal.

4. Tanggung Jawab Sosial

Organisasi membantu dan peduli dalam pengembangan masyarakat sekitar untuk menjadi perusahaan yang ramah lingkungan.

\section{Kerangka Teori}

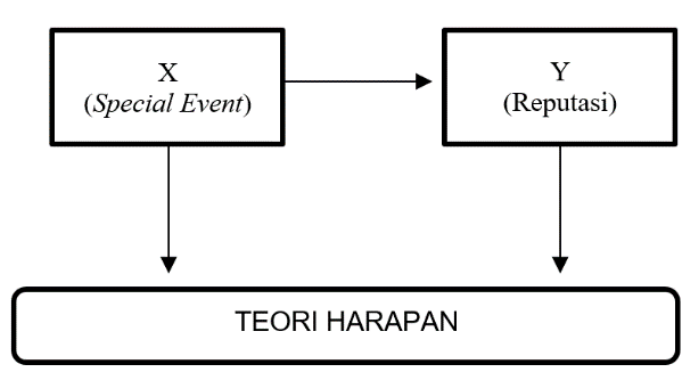

Gambar Kerangka Teori Peneliti, 2018.

Hipotesis Penelitian

Ha: Terdapat pengaruh Special Event

Pembukaan Asian Games ke-18 Tahun

2018 terhadap Reputasi Ketua Panitia

INASGOC 


\section{METODE PENELITIAN}

Menurut Silalahi (2015) menyatakan, "Metode penelitian kuantitatif untuk memecah dan membatasi fenomena menjadi terukur dan kategori sehingga bervariasi dari pengalaman orang-orang untuk dimasukin dalam angka dengan penggunaan di uji”.

Menurut Creswell (2014) postpositivisme adalah mengidentifikasi dan menilai penyebab yang mempengaruhi hasil dan juga bersifat reduksionisme untuk mereduksi gagasan menjadi set untuk diuji seperti menguji variabel dan hipotesis.

Penelitian ini menggunakan metode kuantitatif dimana data diambil saling berpengaruh dari satu variabel ke variabel lain yang dapat diukur untuk mendapatkan data valid.

\section{Populasi dan Sampel}

Populasi yang termasuk di dalam penelitian ini berjumlah 51.000 orang yang menonton langsung Pembukaan Asian Games Ke-18 Tahun 2018. Menentukan sampel melalui rumus slovin yang menggunakan error level $10 \%$ atau 0,1 . Jadi sampel dalam penelitian ini berjumlah 100 responden.

\section{Teknik Pengumpulan Data Data Primer}

Data primer adalah data yang diperoleh langsung dari peneliti ke narasumber dengan menggunakan penyebaran kuisioner skala likerts yang berisikan instrumen pernyataanpernyataan yang terkait dengan penelitian dan berkomunikasi melalui online kepada penonton yang menyaksikan langsung dalam pembukaan Asian Games ke 18 Tahun 2018 di Stadion Utama Gelora Bung Karno, Jakarta.

Peneliti melakukan langkah-langkah distribusi penyebaran kuisioner pada riset lapangan terdiri dari:
1. Mencari data responden melalui jalur pertemanan untuk mendapatkan responden yang menonton langsung pembukaan Asian Games ke-18 tahun 2018 di Stadion Utama Gelora Bung Karno Jakarta dengan karakteristik yang bukan termasuk dalam panitia maupun sukarelawan.

2. Peneliti menghubungi responden melalui media nstru seperti Whatsapp dan Instagram yang mana responden bersedia memberi tanggapan pada kuisioner penelitian.

3. Menyebarkan kuisioner online melalui link google form kepada responden yang berisikan nstrument pernyataan-pernyataan kuisioner penelitian.

\section{Data Sekunder}

Data sekunder diambil dari internet maupun website yang terkait dengan pembukaan acara Asian Games ke-18 tahun 2018, melalui jurnal penelitian dan buku yang relevan dengan penelitian ini.

\section{Teknik Analisis Data}

Penelitian ini menggunakan teknik analisis data melalui Uji Regresi Linear Sederhana, Koefisien Persamaan Regresi, ANOVA, Korelasi, Koefisien Determinasi dan Uji Normalitas. Penelitian ini menggunakan Uji Instrumen untuk menguji validitas dan reliabilitas kuisioner guna mendapatkan data yang berkualitas dan sah.

\section{Operasionalisasi Variabel}

Penelitian ini untuk operasional nstrume menggunakan delapan karakteristik pada special event $(\mathrm{X})$ dan empat elemen pada reputasi (Y) yang sesuai dalam membuat nstrument pernyataan kuisioner. 
Tabel 1.

Operasionalisasi Variabel

\begin{tabular}{|c|c|c|c|}
\hline ס & Dimensi & Indikator & 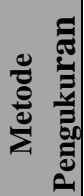 \\
\hline \multirow{16}{*}{ 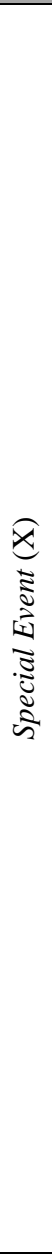 } & \multirow{2}{*}{ Uniqueness } & $\begin{array}{l}\text { Keunikan set panggung } \\
\text { acara }\end{array}$ & \\
\hline & & $\begin{array}{l}\text { Keunikan penampilan } \\
\text { tarian rakyat Indonesia. }\end{array}$ & \\
\hline & \multirow{2}{*}{$\begin{array}{l}\text { Perishabilit } \\
y\end{array}$} & $\begin{array}{l}\text { Ikon aksi Presiden } \\
\text { Republik Indonesia. }\end{array}$ & \\
\hline & & $\begin{array}{l}\text { Penampilan acara secara } \\
\text { kolosal. }\end{array}$ & \\
\hline & \multirow[t]{2}{*}{ Intangibility } & $\begin{array}{l}\text { Perasaan saat menonton } \\
\text { pembukaan acara Asian } \\
\text { Games } 2018 \text {. }\end{array}$ & \\
\hline & & $\begin{array}{l}\text { Penampilan tarian Budaya } \\
\text { Indonesia. }\end{array}$ & \\
\hline & \multirow{2}{*}{$\begin{array}{l}\text { Ritual or } \\
\text { Ceremony }\end{array}$} & $\begin{array}{l}\text { Peresmian pembukaan } \\
\text { Asian Games } 2018 .\end{array}$ & \\
\hline & & $\begin{array}{l}\text { Prosesi penyalaan Api } \\
\text { Obor Asian Games } 2018 .\end{array}$ & \\
\hline & \multirow{2}{*}{$\begin{array}{l}\text { Ambience } \\
\text { and Service }\end{array}$} & $\begin{array}{l}\text { Pembukaan acara yang } \\
\text { spektakuler. }\end{array}$ & \\
\hline & & $\begin{array}{l}\text { Suasana acara yang tertib } \\
\text { dan nyaman. }\end{array}$ & \\
\hline & \multirow{2}{*}{$\begin{array}{l}\text { Personal } \\
\text { Contact and } \\
\text { Interaction }\end{array}$} & $\begin{array}{l}\text { Kekaguman pembukaan } \\
\text { acara Asian Games } 2018 .\end{array}$ & \\
\hline & & $\begin{array}{l}\text { Saling berinteraksi satu } \\
\text { sama lain. }\end{array}$ & \\
\hline & \multirow{2}{*}{$\begin{array}{l}\text { Labour } \\
\text { Intensive }\end{array}$} & $\begin{array}{l}\text { Pembukaan acara Asian } \\
\text { Games } 2018 \text { melibatkan } \\
\text { ribuan orang. }\end{array}$ & $\frac{\frac{\pi}{3}}{\frac{3}{2}}$ \\
\hline & & $\begin{array}{l}\text { Panitia yang bertugas } \\
\text { dibantu oleh sukarelawan. }\end{array}$ & $\frac{\pi}{5}$ \\
\hline & \multirow{2}{*}{$\begin{array}{l}\text { Fixed } \\
\text { Timescale }\end{array}$} & $\begin{array}{l}\text { Skala waktu sesuai dengan } \\
\text { durasi. }\end{array}$ & \\
\hline & & $\begin{array}{l}\text { Penyelenggaraan acara saat } \\
\text { malam hari. }\end{array}$ & \\
\hline \multirow{7}{*}{ 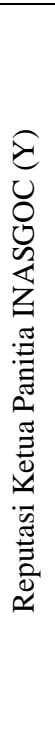 } & \multirow[b]{2}{*}{ Kredibilitas } & $\begin{array}{l}\text { Mampu mengelola acara } \\
\text { secara professional. }\end{array}$ & \\
\hline & & $\begin{array}{l}\text { Dipercaya untuk } \\
\text { menyelenggarakan acara } \\
\text { yang spektakuler. }\end{array}$ & \\
\hline & \multirow[b]{2}{*}{ Terpercaya } & $\begin{array}{l}\text { Mendapatkan kepercayaan } \\
\text { dari penonton. }\end{array}$ & \\
\hline & & $\begin{array}{l}\text { Ketua panitia layak } \\
\text { dipercaya dapat } \\
\text { mensukseskan acara. }\end{array}$ & \\
\hline & \multirow[b]{2}{*}{$\begin{array}{l}\text { Keterandala } \\
\mathrm{n}\end{array}$} & $\begin{array}{l}\text { Membangun reputasi } \\
\text { menjadi hasil positif. }\end{array}$ & \\
\hline & & $\begin{array}{l}\text { Keandalan dalam } \\
\text { memberikan kualitas } \\
\text { fasilitas-fasilitas yang baik }\end{array}$ & \\
\hline & $\begin{array}{l}\text { Tanggung } \\
\text { Jawab } \\
\text { Sosial }\end{array}$ & $\begin{array}{l}\text { Memberikan edukasi ramah } \\
\text { lingkungan untuk } \\
\text { pengolahan limbah Bahan } \\
\text { Berbahaya dan Beracun } \\
\text { (B3) kepada masyarakat. }\end{array}$ & \\
\hline
\end{tabular}

Sumber: Data Olahan Peneliti, 2019.

\section{HASIL DAN PEMBAHASAN}

\section{Hasil Uji Validitas Penelitian}

Menurut Widoyoko (2012, p. 147149) suatu butir instrumen dikatakan valid apabila mempunyai validitas yang tinggi jika skor pada butir mempunyai korelasi dengan skor total.

Uji validitas dapat menggunakan derajat bebas (degree of freedom). Degree of freedom adalah fungsi dari masing-masing faktor-faktor seperti jumlah dari subjek dan jumlah dari kelompok. Menentukan nilai df melalui formula $\mathrm{N}-2$ dimana $\mathrm{N}$ adalah jumlah subjek menghasilkan $r_{\text {hitung }}>r_{\text {tabel }}$ dari tingkat probabilitas, maka butir instrumen dikatakan valid (Silalahi, 2015).

Uji validitas penelitian ini menggunakan degree of freedom yang mana terdapat hasil formula N-2 $(100-2=98)$ dengan $\alpha \quad 0,1$ dan melalui SPSS yang menunjukkan 16 pernyataan pada variabel special event pembukaan Asian Games ke 18 tahun 2018 (X) terdapat hasil $\mathrm{r}_{\text {hitung }}>\mathrm{r}_{\text {tabel }}$ $(0,165)$ dengan hasil valid.

Uji validitas penelitian ini menggunakan degree of freedom yang mana terdapat hasil formula N-2 $(100-2=98)$ dengan $\alpha \quad 0,1$ dan melalui SPSS yang menunjukkan 7 pernyataan pada variabel reputasi ketua panitia INASGOC (Y) terdapat hasil $r_{\text {hitung }}>r_{\text {tabel }}(0,165)$ dengan hasil valid.

\section{Hasil Uji Reliabilitas Penelitian}

Penelitian yang menggunakan Alpha Cronbach untuk menguji relibialitas terdapat hasil pada variabel $\mathrm{X}$ adalah 0,891 dan variabel Y adalah 0,907. Menurut Nunnally dan Berstein (dalam Uyanto, 2009) dapat dikatakan reliabel melewati nilai Alpha Cronbach minimal 0,70. 


\section{Hasil Analisis Korelasi}

Tabel 2.

Hasil Analisis Korelasi

\begin{tabular}{|c|c|c|c|}
\hline \multicolumn{4}{|c|}{ Correlations } \\
\hline & & $\begin{array}{c}\text { Special } \\
\text { Event }\end{array}$ & Reputasi \\
\hline \multirow{3}{*}{$\begin{array}{c}\text { Special } \\
\text { Event }\end{array}$} & \begin{tabular}{|l} 
Pearson \\
Correlation
\end{tabular} & 1 & $.628^{* * *}$ \\
\hline & Sig. (2-tailed) & & .000 \\
\hline & $\mathrm{N}$ & 100 & 100 \\
\hline \multirow[t]{3}{*}{ Reputasi } & $\begin{array}{l}\text { Pearson } \\
\text { Correlation }\end{array}$ & $.628^{* *}$ & 1 \\
\hline & Sig. (2-tailed) & .000 & \\
\hline & $\mathrm{N}$ & 100 & 100 \\
\hline
\end{tabular}

Sumber: Data Olahan Peneliti, 2019.

Berdasarkan tabel hasil korelasi di atas, diketahui bahwa variabel special event $(\mathrm{X})$ memiliki nilai signifikansi 0,000 lebih kecil dari $\propto=0,1$ dengan variabel reputasi $(\mathrm{Y})$, maka hasil ini menunjukkan terdapat korelasi antara dua variabel. Hasil pada Pearson Correlation Product Moments antara special event pembukaan Asian Games ke 18 tahun 2018 terhadap reputasi ketua panitia INASGOC kuat positif yaitu 0,628. Artinya positif adalah hubungan antara variabel $\mathrm{X}$ dan Y searah dan dinyatakan bahwa semakin kuat special event pembukaan Asian Games ke 18 tahun 2018, maka semakin kuat reputasi ketua panitia INASGOC.

\section{Hasil Analisis Koefisien Determinasi}

Tabel 3.

Hasil Analisis Koefisien Determinasi

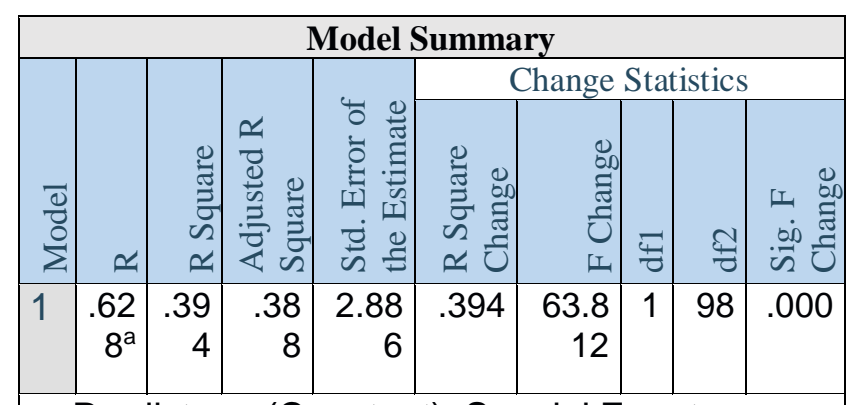

a. Predictors: (Constant), Special Event

Sumber: Data Olahan Peneliti, 2019.
Berdasarkan di atas, hasil koefisien determinasi diketahui sebesar 0,394 atau $39,4 \%$ merupakan bahwa besar pengaruh special event pembukaan acara Asian Games ke-18 tahun 2018 terhadap reputasi ketua panitia INASGOC adalah $39,4 \%$, dimana $60,6 \%$ lainnya dipengaruhi oleh faktor-faktor lain diluar variabel $\mathrm{x}$.

\section{Hasil Analisis Regresi Sederhana}

Tabel 4.

Hasil Analisis Regresi Sederhana

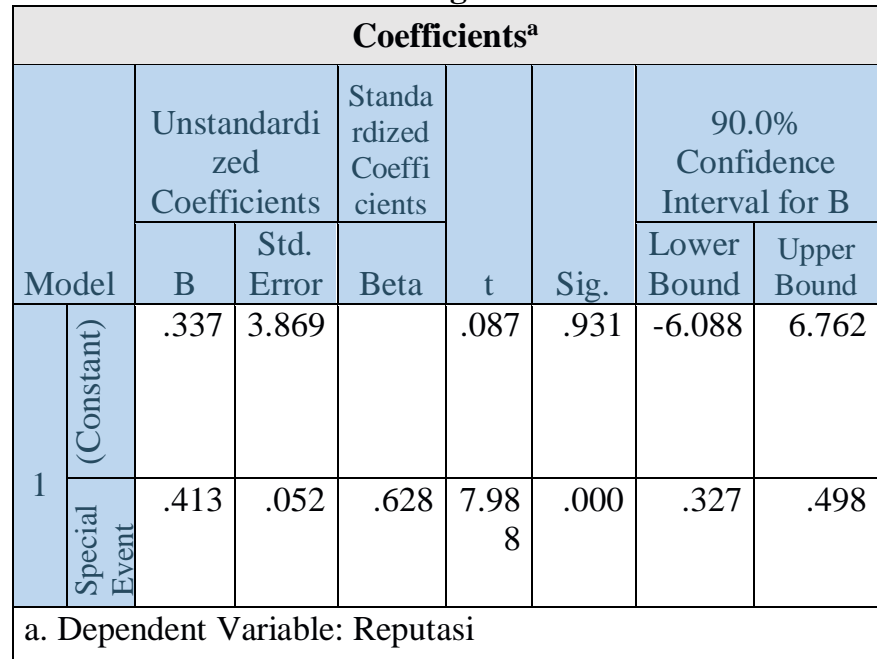

Sumber: Data Olahan Peneliti, 2019.

Berdasarkan tabel di atas, nilai konstanta dalam penelitian sebesar 0,337. Angka nilai konstanta menunjukkan bahwa dengan adanya special event pembukaan Asian Games ke 18 tahun 2018 maka nilai konsistensi reputasi ketua panitia INASGOC adalah 0,413. Angka koefisien regresi 0,413 berarti setiap penambahan 1 special event, maka reputasi akan meningkat sebesar 0,413.

Dari hasil analisis diperoleh $t_{\text {hit }}=$ $7.988>\mathrm{t}$ tabel (1.660) maka $\mathrm{H}_{\mathrm{o}}$ ditolak dan $\mathrm{H}_{\mathrm{a}}$ diterima, artinya koefisien regresi signifikan atau nilai signifikansi $0,000 / 2=0<0,1$ atau $\mathrm{H}_{\mathrm{o}}$ ditolak. Nilai regresi bersifat positif dinyatakan bahwa special event pembukaan Asian Games ke 18 tahun 2018 berpengaruh positif terhadap reputasi ketua panitia INASGOC dengan persamaan regresi yaitu:

$Y=0,337+0,413 X$ 


\section{Hasil Uji ANOVA}

Tabel 5.

Hasil Uji ANOVA

\begin{tabular}{|c|c|c|c|c|c|c|}
\hline \multicolumn{7}{|c|}{ ANOVA $^{a}$} \\
\hline \multicolumn{2}{|c|}{ Model } & $\begin{array}{c}\text { Sum of } \\
\text { Squares }\end{array}$ & df & $\begin{array}{l}\text { Mean } \\
\text { Square }\end{array}$ & F & Sig. \\
\hline \multirow{3}{*}{1} & $\begin{array}{l}\text { Regress } \\
\text { ion }\end{array}$ & 531.377 & 1 & 531.377 & $\begin{array}{r}63.81 \\
2\end{array}$ & $.000^{\mathrm{b}}$ \\
\hline & $\begin{array}{l}\text { Residu } \\
\text { al }\end{array}$ & 816.063 & 98 & 8.327 & & \\
\hline & Total & 1347.440 & 99 & & & \\
\hline
\end{tabular}

a. Dependent Variable: Reputasi

b. Predictors: (Constant), Special Event

Sumber: Data Olahan Peneliti, 2019.

Berdasarkan hasil tabel di atas, dapat disimpulkan uji signifikansi ANOVA persamaan garis regresi $\mathrm{F}$ hitung adalah $63,812>\mathrm{t}$ tabel $(2,76)$ maka $\mathrm{H}_{\mathrm{o}}$ ditolak dan $\mathrm{H}_{\mathrm{a}}$ diterima, artinya special event berpengaruh terhadap reputasi atau nilai signifikansi adalah $0,000<0,1$ atau $\mathrm{H}_{\mathrm{o}}$ ditolak. Hasil ini menunjukkan bahwa (variabel $\mathrm{x}$ ) special event pembukaan Asian Games ke 18 tahun 2018 sangat mempengaruhi (variabel y) reputasi ketua panitia INASGOC.

\section{Hasil Uji Normalitas}

Tabel 6.

Hasil Uji Normalitas

\begin{tabular}{|c|c|c|}
\hline \multicolumn{3}{|c|}{ One-Sample Kolmogorov-Smirnov Test } \\
\hline & & $\begin{array}{c}\text { Unstandardized } \\
\text { Residual }\end{array}$ \\
\hline \multicolumn{2}{|c|}{$\mathrm{N}$} & 100 \\
\hline \multirow[b]{2}{*}{$\begin{array}{l}\text { Normal } \\
\text { Parameters }{ }^{\mathrm{a}, \mathrm{b}}\end{array}$} & Mean & .0000000 \\
\hline & Std. Deviation & .79350863 \\
\hline \multirow{3}{*}{$\begin{array}{l}\text { Most Extreme } \\
\text { Differences }\end{array}$} & Absolute & .093 \\
\hline & Positive & .055 \\
\hline & Negative & -.093 \\
\hline \multicolumn{2}{|l|}{ Test Statistic } & .093 \\
\hline \multicolumn{2}{|c|}{ Asymp. Sig. (2-tailed) } & $.000^{\mathrm{c}}$ \\
\hline \multicolumn{3}{|c|}{ a. Test distribution is Normal. } \\
\hline \multicolumn{3}{|c|}{ b. Calculated from data. } \\
\hline \multicolumn{3}{|c|}{ c. Lilliefors Significance Correction. } \\
\hline
\end{tabular}

Sumber: Data Olahan Peneliti, 2019
Normal P-P Plot of Regression Standardized Residual

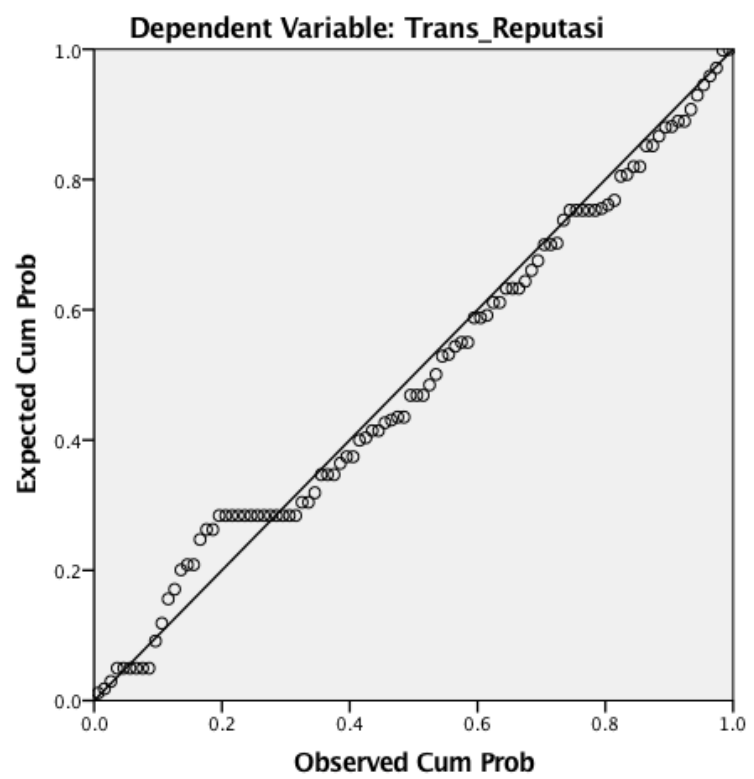

Gambar Normal P-Plot

Sumber: Data Olahan Peneliti, 2019

Berdasarkan di atas terdapat hasil Dhitung $0,093<0,121$ artinya data berdistribusi normal, namun nilai signifikansi $0,003<0,1$.

Menurut Central Limit Theorem (Limit Teorem Pusat) bahwa jika data $\mathrm{N}>30$ maka distribusi dianggap data berdistribusi normal (Syamsuddin, 2013).

\section{PENUTUP}

\section{Simpulan}

Berdasarkan hasil analisa dan pembahasan, hal ini terbukti dari teori harapan yang mana pembukaan Asian Games ke-18 tahun 2018 mempunyai pengaruh terhadap ketua panitia INASGOC. Jadi yang telah dikerjakan ketua panitia INASGOC mendapatkan hasil yang sesuai dengan harapan terdiri dari:

1. Berdasarkan hasil analisis data penelitian terdapat pengaruh positif dan signifikan antara special event pembukaan Asian Games ke-18 tahun 2018 terhadap reputasi ketua panitia INASGOC.

2. Berdasarkan hasil analisis data penelitian pada koefisien determinasi terdapat besar pengaruh special event pembukaan Asian Games ke-18 tahun 2018 terhadap 
reputasi ketua panitia INASGOC adalah $39,4 \%$, dimana $60,6 \%$ lainnya dipengaruhi oleh faktor-faktor lain diluar variabel $\mathrm{x}$.

\section{Saran Akademis}

Penelitian ini dapat digunakan dalam memahami special event dan reputasi seseorang maupun organisasi lebih dalam lagi dan pembaca dapat melihat sukses special event pembukaan Asian Games ke-18 tahun 2018 yang sudah dibangun dan mengelola reputasi INASGOC dengan baik dan tepat.

Penelitian ini bisa dikembangkan lebih lanjut lagi dengan mencari atau menambah variabel lain yang berpengaruh terhadap reputasi ketua panitia INASGOC selain special event pembukaan Asian Games ke-18 tahun 2018. Ada 60,6\% terdapat faktor-faktor lain untuk penelitian selanjutnya misalnya: Media Public Relations, Publikasi, Kepercayaan Publik, Inovasi Produk, dan Komunikasi.

\section{Saran Praktis}

1. Perishability yang dilakukan oleh Public Relations dapat menggunakan konsep-konsep yang hampir sama untuk menampilkan suatu acara yang besar guna lebih menarik kedepannya.

2. Ambience and Service yang dilakukan dalam penelitian ini sudah cukup baik, sebagai Public Relations dalam suatu acara besar perlu memperhatikan halhal terkecil sampai terbesar seperti menciptakan suasana kenyamanan dan pelayanan yang baik kepada penonton guna mendapatkan hasil yang lebih maksimal daripada sebelumnya.

3. Fixed Timescale berperan penting dalam suatu acara yang besar sebagai Public Relations perlu memperhatikan dalam mengatur durasi tampilan acara yang efektif karena penonton lebih menyukai menonton acara secara langsung dengan menghasilkan pengalaman yang spektakuler.

\section{DAFTAR PUSTAKA}

Aryska, M., \& Kasmirudin. (2017). Pengaruh Reputasi Perusahaan Dan Kualitas Pelayanan Terhadap Kepuasan Pasien (Kasus Rumah Sakit Islam Ibnu Sina Pekanbaru). Jom Fisip, 4(1), Februari, 1-15. Retrieved from https://jom.unri.ac.id/index.php/JOMF SIP/article/view/13900

Baqiroh, N. F. A. B. (2018). Penonton Opening Ceremony Asian Games 2018 Puas. Retrieved from Sport.bisnis.com website: http://sport.bisnis.com/read/20180818/ 59/829326/penonton-openingceremony-asian-games-2018-puas

Creswell, J. W. (2014). Research Design Qualitative, Quantitative and Mixed Methods Approaches 4th Ed. Retrieved from https://libgen.lc/ads.php?md5=A000C DF97760A63A36F28A042A568EE5

Gassing, D. S. S. . S. (2016). Public Relations. Yogyakarta: Andi Yogyakarta.

Goldblatt, J. (2013). Special Events Creating and Sustaining a New World for Celebration. Retrieved from http://gen.lib.rus.ec/book/index.php?m d5=E60AEEC95D18B226F95E707135 05137B

Hartono, N. A., Dida, S., \& Hafiar, H. (2016). PELAKSANAAN KEGIATAN SPECIAL EVENT JAKARTA GOES PINK OLEH LOVEPINK INDONESIA. Jurnal Komunikasi, 10(2), 161-172. Retrieved from https://doi.org/10.21107/ilkom.v10i2.2 519

Helm, Sabrina; Gobbers , Kerstin Liehr; Storck, C. (2011). Reputation Management. Retrieved from http://gen.lib.rus.ec/book/index.php?m d5=EED8A712E5A68CCD968B5B45 4DF8B1AC

Marliani, S. (2016). Motivasi Kerja Dan Kepuasaan Kerja Terhadap Kinerja Karyawan (Studi pada Karyawan PT. Bank Negara Indonesia (Persero) Tbk 
Cabang Karawang. Jurnal Buana Akuntansi, 1(1), 47-75. Retrieved from http://journal.ubpkarawang.ac.id/index. php/Akuntansi/article/view/43/42

Matthews, D. (2016). Special Event Production: The Resources, Second Edition. Retrieved from http://gen.lib.rus.ec/book/index.php?m d5=24D28F7215333F28372A4D2CD4 ADD4DB

Pudjiastuti, W. (2010). Special Event Alternatif Jitu Membidik Pasar. Jakarta: PT Elex Media Komputindo.

Raya, M. (2018). Pembukaan Asian Games Diprediksi Dihadiri 40 Ribu Penonton. Retrieved from Sport.detik.com website:

https://www.era.id/read/dmUpAAmerekam-asian-games-dari-masa-kemasa

Ruslan, R. (2016). Manajemen Public Relations dan Media Komunikasi. Jakarta: PT RajaGrafindo Persada.

Sari, O. K. (2018). Spektakuler, Pembukaan Asian Games 2018 Menyihir Penonton. Retrieved from Detiksport.com website: https://sport.detik.com/sportlain/4172412/spektakuler-pembukaanasian-games-2018-menyihir-penonton

Shone, Anton; Parry, B. (2010). Successful Event Management A Pratical Handbook: Third Edition. Retrieved from

http://gen.lib.rus.ec/book/index.php?m d5=AD181675185820C6250A36E236 B3F1A2

Silalahi, D. U. (2015). Metode Penelitian Sosial Kuantitatif. Bandung: PT Refika Aditama.

Surbakti, R. T. (2014). Pengaruh Motivasi Kerja Terhadap Kinerja Karyawan Golongan 1 Di Universitas Katolik Parahyangan. E-Journal Graduate Unpar Part A : Economics, 211-232. Retrieved from http://journal.unpar.ac.id/index.php/unp argraduate/article/view/1043

Sutrisno, E. (2009). Manajemen Sumber Daya
Manusia Edisi Pertama. Retrieved from https://books.google.co.id/books?id=O hZNDwAAQBAJ\&pg=PR3\&dq=Mana jemen+Sumber+Daya+Manusia+Edisi + Pertama\&hl=en\&sa $=$ X\&ved $=0$ ahUK EwiEmbPy25vfAhUZbn0KHT_NDco Q6AEINjAB\#v=onepage $\& \mathrm{q}=$ Manajem en Sumber Daya Manusia Edisi Pertama\& $\mathrm{f}=$ false

Syaiyid, E., Utami, H. N., \& Riza, M. F. (2013). PENGARUH GAYA KEPEMIMPINAN TERHADAP MOTIVASI KERJA (Studi Pada Karyawan Radar Malang PT. Malang Intermedia Pers). Jurnal Administrasi Bisnis (JAB), 1(1), 104-113. Retrieved from

http://administrasibisnis.studentjournal. ub.ac.id/index.php/jab/article/view/16

Syamsuddin. (2013). Perananan Matematika Dan Statistika Dalam Menganalisas

Pengaruh Kepemimpinan Terhadap Pertumbuhan Usaha Indsutri Kecil Di Sulawesi Selatan. Jurnal Matematika, Statistika Dan Komputasi, 9(2), Januari, 123-130. Retrieved from http://journal.unhas.ac.id/index.php/jms k/article/download/3404/1941

Tamtomo, A. B. (2018). INFOGRAFIK: Profil Erick Thohir, Ketua Tim Kampanye Jokowi-Ma'ruf. Retrieved from Kompas.com website: https://nasional.kompas.com/read/2018 /09/08/17305261/infografik-profilerick-thohir-ketua-tim-kampanyejokowi-maruf

Triamanah. (2012). Reputasi Dalam Kerangka Kerja Public Relations. Jurnal Ilmiah Komunikasi Makna, 3(1), Februari, 92102. Retrieved from http://jurnal.unissula.ac.id/index.php/m akna/article/view/117/93

Uyanto, S. S. (2009). Pedoman Analisis Data Dengan SPSS. Yogyakarta: Graha Ilmu.

Widoyoko, E. P. (2012). Teknik Penyusunan Instrumen Penelitian. Yogyakarta: Pustaka Pelajar 